\title{
FAKTOR-FAKTOR YANG MEMPENGARUHI MINAT BELI KONSUMEN TEMPE (STUDI KASUS PADA UD. YUZAK KECAMATAN PANJI KABUPATEN SITUBONDO)
}

\author{
Syarif Rahmad Hidayat1), Yasmini Suryaningsih ${ }^{2 *}$ \\ Program Studi Agribisnis, Fakultas Pertanian, Universitas Abdurachman Saleh Situbondo \\ Email Korespondensi : jasminumsambac95@gmail.com
}

\begin{abstract}
Abstrak
Tujuan penelitian ini adalah untuk mengetahui minat beli konsumen dan faktor yang mempengaruhinya terhadap pembelian tempe pada UD. Yuzak di Kecamatan Panji Kabupaten Situbondo. Hasil penelitian menunjukkan bahwa minat beli konsumen akan produk tempe yang dijual oleh UD. Yuzak berada pada ketegori sangat tinggi. Faktorfaktor yang mempengaruhi minat beli konsumen tempe pada UD. Yuzak adalah pelayanan dan psikologis, sedangkan harga dan kualitas tidak berpengaruh terhadap minat beli konsumen. Hal ini dapat dijabarkan sebagai berikut yaitu : a). Tidak terdapat pengaruh harga terhadap minat beli konsumen produk tempe dengan t-hitung sebesar 1,033 dan ttabel sebesar 1,986 (t-hitung < t-tabel). b). Tidak terdapat pengaruh kualitas terhadap minat beli konsumen produk tempe dengan t-hitung sebesar 0,710 dan t- tabel sebesar 1,986 (t-hitung < t-tabel). c). Terdapat pengaruh pelayanan terhadap minat beli konsumen produk tempe dengan t-hitung sebesar 2,248 dan t- tabel sebesar 1,986 (t-hitung $>\mathrm{t}$ tabel). d). Terdapat pengaruh psikologis terhadap minat beli konsumen produk tempe dengan t-hitung sebesar 2,039 dan t- tabel sebesar 1,986 (t-hitung > t-tabel)
\end{abstract}

Kata Kunci : Minat beli, tempe, UD. Yuzak

\begin{abstract}
The purpose of this study was to determine consumer buying interest and the factors that influence it on the purchase of tempe at UD. Yuzak in Panji, Situbondo. The results showed that consumers buying interest in tempe products sold by UD. Yuzak is in a very high category. Factors that influence the buying interest of tempe consumers at UD. Yuzak include service and psychological aspect, whereas price and quality have no effect on consumer buying interest. This can be described as follows: a). There is no effect of price on consumer buying interest of tempe with a $t$-count of 1.033 and a $t$-table of 1.986 ( $t$-count $<t$-table). $b$ ). There is no influence of quality on consumer buying interest of tempe with a t-count of 0.710 and a $t$-table of 1.986 ( $t$-count $<t$-table). $c$ ). There is a service effect on consumers' buying interest in tempe with a $t$-count of 2,248 and a $t$-table of 1,986 ( $t$-count $>t$-table). $d$ ). There is a psychological influence on consumer buying interest of tempe with a $t$-count of 2.039 and a t- table of 1.986 ( $t$-count $>$ t-table).
\end{abstract}

Keyword : Factors, Influence, Consumer Interest 


\section{PENDAHULUAN}

Sektor pertanian dan industri merupakan sektor yang terkait satu sama lain, dimana pertanian sebagai penyedia bahan baku, sedangkan industri mengolah hasil pertanian untuk memperoleh nilai tambah. Industri kecil mempunyai peranan yang sangat besar tehadap roda perekonomian suatu negara. Menurut M. Irfan dalam Anoraga dan Sudantoko (2002), peranan usaha kecil itu dapat meningkatkan ekspor non migas, penyerapan tenaga kerja, meningkatkan kualitas sumber daya manusia, dan berkontribusi terhadap Produk Domestik Bruto (PDB). Menurut Sarwono (2004), kontribusi industri kecil terhadap produk domestik bruto (PDB) baru mencapai 14\%, hal ini menjadi tantangan bagi para pengusaha kecil untuk meningkatkan usahanya.

Industri kecil yang mengolah hasil-hasil pertanian (agroindustri) tahan terhadap dampak krisis ekonomi bersifat padat karya, karena agroindustri merupakan salah satu alternatif dalam membangun kembali perekonomian Indonesia saat ini (Anoraga dan Sudantoko, 2002). Selain dapat menciptakan lapangan kerja bagi masyarakat sekitar perusahaan, juga dapat menciptakan nilai tambah bagi produk pertanian khususnya pangan.

Perkembangan Kabupaten Situbondo sebagai salah satu pusat perdagangan dan bisnis menimbulkan banyak perubahan. Perubahan yang paling jelas terlihat adalah timbulnya persaingan bisnis yang semakin tinggi. Selain timbulnya persaingan bisnis yang tinggi, pola pikir dan perilaku masyarakat juga mengalami banyak kemajuan. Perkembangan pola pikir tersebut, misalnya masyarakat lebih tertarik untuk menginvestasikan uang mereka dengan mendirikan usaha seperti pabrik tempe agar dapat menghasilkan keuntungan bagi mereka.

Persaingan merupakan hal yang sangat menentukan keberhasilan maupun kegagalan suatu perusahaan dimana perusahaan yang tidak mampu bersaing akan segera tersisih dari lingkungan pasar. Sebaliknya, persaingan akan semakin dimenangkan oleh perusahaan yang inovatif dan kreatif dalam pengelolaan bisnisnya serta perusahaan yang berhasil memuaskan konsumen mereka. Hubungan yang baik akan tercipta apabila usaha bisnis mampu memberikan kepuasan kepada konsumen melalui produk yang dihasilkan sehingga pelanggan akan tetap setia untuk membeli produk yang dihasilkan. Usaha bisnis juga harus mampu menciptakan dan memelihara hubungan baik dengan lingkungan secara umum dan konsumen secara khusus.

Perilaku konsumen adalah tindakan-tindakan, proses dan hubungan sosial yang dilakukan individu, kelompok dan organisasi dalam mendapatkan, menggunakan suatu produk atau lainnya sebagai suatu akibat dari pengalamannya dengan produk, pelayanan, harga dan sumber- sumber lainnya (Rosnani, 2010). Konsumen memutuskan membeli dari segi harga, kualitas, pelayanan, dan faktor emosional (psikologis) yang diterimanya. Oleh karena itu, setiap perusahaan harus mampu memberikan kepuasan kepada para pelanggannya dengan cara menyediakan produk yang mutunya lebih baik atau berkualitas, harganya murah (terjangkau), penyajian atau penyerahan produk yang cepat dan pelayanan yang baik daripada para pesaing. Pelayanan yang baik mampu memberikan kepuasan konsumen dan meningkatkan minat beli konsumen, serta akan mampu mempertahankan konsumen yang sudah ada (konsumen lama) untuk terus membeli produk yang ditawarkan bahkan dapat pula menarik minat calon konsumen baru. Kebersihan pun terjamin, baik dalam hal produk yang disajikan, yang melewati proses yang higienis.

Fenomena yang terjadi saat ini adalah terdapat banyaknya pabrik tempe yang menjual produk tempenya ke pedagang besar atau kecil dan juga langsung kepada konsumen. Cara pengusaha tempe memasarkan produknya pada umumnya menggunakan strategi yakni harganya lebih murah dan kualitas produknya baik dibandingkan dengan harga dan kualitas produk pada pengusaha lain. 
Pabrik tempe UD Yuzak yang beralamat Kelurahan Mimbaan Kecamatan Panji Kabupaten Situbondo ini telah banyak dikenal oleh masyarakat Situbondo. Tempe yang dihasilkan di pabrik ini pun halal dan aman untuk dikonsumsi oleh berbagai kalangan masyarakat. Pabrik ini dapat mempertahankan eksistensinya di tengah persaingan bisnis yang semakin tinggi di Kabupaten Situbondo, bahkan semakin menunjukkan kemampuannya untuk terus berkembang dengan pesat. Hal ini membuktikan bahwa pabrik tempe yang bergerak di bidang usaha yang berhubungan langsung dengan konsumen mampu memenuhi harapan dan kebutuhan para konsumennya, oleh strategi yang dijalankan yaitu dengan harga yang lebih murah dan kualitas produknya baik, meningkatkan kualitas produk yang dihasilkan untuk dapat memenuhi kebutuhan konsumen sehingga mampu mempertahankan keberhasilan yang diperoleh, seperti yang telah dilakukan oleh pabrik tempe UD. Yuzak hingga saat ini.

Melihat para pembeli yang selalu ramai dalam per minggunya. Pabrik tempe UD. Yuzak ini menghabiskan 1,8 ton lebih kacang kedelai per bulannya dengan hasil pendapatan perbulan kurang lebih 15 juta. Karena kualitas dan ukurannya yang berbeda, para konsumen merasa tertarik dan membeli produk tempe UD. Yuzak ini karena dapat memilih produk tempe sesuai kualitas dan ukurannya dengan harga yang murah dan kualitas produknya baik.

Berdasarkan uraian latar belakang masalah yang telah dikemukakan di atas, peneliti tertarik untuk melakukan penelitian mengenai minat beli konsumen dengan judul "Faktor-Faktor Yang Mempengaruhi Minat Beli Konsumen Tempe (Studi Kasus Pada UD. Yuzak Kecamatan Panji Kabupaten Situbondo)", dengan rumusan masalah sebagai berikut:

1. Bagaimana minat beli konsumen dalam pembelian tempe pada UD. Yuzak Kecamatan Panji Kabupaten Situbondo?

2. Faktor apa saja yang mempengaruhi minat beli konsumen tempe pada UD. Yuzak Kecamatan Panji Kabupaten Situbondo?

\section{METODE PENELITIAN}

\section{Tempat dan Waktu Penelitian}

Penentuan daerah penelitian dilakukan secara sengaja (Purposive Method) yang dilaksanakan pada UD. Yuzak di Kelurahan Mimbaan Kecamatan Panji Kabupaten Situbondo. Lokasi ini dipilih atas pertimbangan sebagai berikut :

1. UD. Yuzak di Kecamatan Panji merupakan usaha pembuatan tempe yang memiliki pasar tersendiri bagi masyarakat sehingga permintaan akan tempe dari tempat tersebut tidak pernah sepi

2. UD. Yuzak di Kecamatan Panji adalah usaha pembuatan tempe di kawasan Panji yang sejak tahun 1991 sampai sekarang semakin berkembang dan diperhitungkan dalam usaha produksi tempe.

3. Terdapat rata-rata 60 konsumen tempe perhari pada UD. Yuzak di Kecamatan Panji sehingga mempermudah penentuan jumlah sampel.

Waktu penelitian yang digunakan oleh peneliti pada bulan Juli 2019 sampai bulan Agustus 2019

\section{Teknik Pengumpulan Data}

Dalam suatu penelitian, metode pengumpulan data merupakan suatu faktor yang penting, karena perhitungan diperoleh dari data yang didapatkan dalam penelitian. Metode yang digunakan dalam penelitian ini adalah: 
1. Kuesioner (Angket)

Data yang ingin diperoleh peneliti yakni dengan cara memberi angket kepada konsumen tempe UD. Yuzak Kecamatan Panji. Agar data yang terkumpul dapat berwujud kuantitatif, maka setiap alternatif jawaban diberikan skor atau nilai.

2. Observasi

Proses observasi dilakukan peneliti pada saat pra riset di lapangan guna mengetahui masalah-masalah yang ada pada UD. Yuzak Kecamatan Panji, dengan pertimbangan masalah-masalah yang ada.

3. Wawancara

Sugiyono (2017) mengemukakan bahwa wawancara digunakan sebagai teknik pengumpulan data apabila peneliti ingin melakukan studi pendahuluan untuk menemukan permasalahan yang diteliti, dan apabila peneliti ingin mengetahui hal-hal dari responden yang lebih mendalam dari respondennya sedikit/kecil. Metode ini digunakan untuk mengumpulkan informasi atau data dengan mempelajari dokumendokumen pada UD. Yuzak Kecamatan Panji.

4. Dokumentasi

Dokumen yang digunakan peneliti disini berupa foto, gambar, serta data-data dari UD. Yuzak Kecamatan Panji untuk memudahkan peneliti memperoleh informasi yang diperlukan selama proses penelitian berlangsung

\section{Teknik Analisis Data}

Untuk hipotesa yang pertama yaitu mengetahui bagaimana minat beli konsumen dalam pembelian tempe pada UD. Yuzak Kecamatan Panji Kabupaten Situbondo dilakukan dengan analisis deskriptif menggunakan index kategori, rincian index kategori dapat diuraikan sebagai berikut.

1. Penghitungan Interval

Sebelum menentukan index kategori, terlebih dahulu menentukan interval pada setiap kategori dari minat beli konsumen yang akan dijadikan acuan untuk mencari hipotesa.

Interval Presentase $=\frac{100 \%}{\text { Kelas Interval }}$

Interval Presentase $=\frac{100 \%}{5}=20$

Maka tabel kelas intervalnya adalah sebagai berikut.

Tabel 1. Kelas Interval Minat Beli Konsumen

\begin{tabular}{llc}
\hline & \multicolumn{1}{c}{ Kelas } & Keterangan \\
\hline $0 \%$ & $-19,99 \%$ & Sangat Rendah \\
$20 \%$ & $-39,99 \%$ & Rendah \\
$40 \%$ & $-59,99 \%$ & Netral atau Cukup \\
$60 \%$ & $-79,99 \%$ & Tinggi \\
$80 \%$ & $-100 \%$ & Sangat Tinggi \\
\hline
\end{tabular}

Sumber : Sujarweni 2012

2. Index Kategori

Index kategori digunakan untuk menentukan variabel minat beli memiliki kategori rendah ataupun tinggi pada suatu penelitian. Rumus index kategori dapat diuraikan sebagai berikut: 
Keterangan:

Index Kategori \% = Total Skor / (Y.I) x 100\%

$$
\begin{aligned}
\text { Total Skor = } & \text { Jumlah perolehan skor pada setiap indikator } \\
\mathrm{Y} & \text { Jumlah skor tertinggi skala likert } \mathrm{x} \text { jumlah responden } \\
& (5 \times 97=485) \\
\mathrm{I} & \text { Jumlah pernyataan dalam setiap indikator }
\end{aligned}
$$

Untuk hipotesa yang kedua yaitu mengetahui faktor yang mempengaruhi minat beli konsumen pada UD. Yuzak Kecamatan Panji Kabupaten Situbondo dilakukan dengan analisis regresi linier berganda.

1 Analisis Regresi Linier Berganda

Analisis ini digunakan untuk mengetahui seberapa besar pengaruh variabel bebas yaitu harga $\left(\mathrm{X}_{1}\right)$, kualitas produk $\left(\mathrm{X}_{2}\right)$, pelayanan $\left(\mathrm{X}_{3}\right)$ dan psikologis $\left(\mathrm{X}_{4}\right)$ terhadap varibel terkait yaitu minat beli konsumen (Y) tempe UD. Yuzak Kecamatan Panji. Sujerwani (2012) mengemukakan bahwa untuk mengetahui pengaruh variabel bebas terhadap variabel terkait digunakan rumus analisis regresi linier berganda sebagai berikut:

$$
\mathrm{Y}=\mathrm{a}+\mathrm{b}_{1} \mathrm{X}_{1}+\mathrm{b}_{2} \mathrm{X}_{2}+\mathrm{b}_{3} \mathrm{X}_{3}+\mathrm{b}_{4} \mathrm{X}_{4}+\mathrm{e}
$$

Keterangan :

$\begin{array}{ll}\mathrm{Y} & \text { : Minat Beli Konsumen } \\ \mathrm{X}_{1} & \text { : Harga } \\ \mathrm{X}_{2} & \text { : Kualitas Produk } \\ \mathrm{X}_{3} & \text { : Pelayanan } \\ \mathrm{X}_{4} & \text { : Psikologis } \\ \mathrm{a} & \text { : Konstanta } \\ \mathrm{b}_{1} \mathrm{~b}_{2} \mathrm{~b}_{3} & \text { : Koefisien Regresi } \\ \mathrm{e} & \text { : Error }\end{array}$

2 Uji Parsial (Uji t)

Uji t digunakan untuk melihat secara persial bagaimana pengaruh variabel bebas (X) terhadap variabel terikat $(\mathrm{Y})$, guna menguji hipotesis yang telah ditetapkan memilki pengaruh atau tidak (Sujerwani, 2012):

$$
\mathrm{t}=\frac{r \sqrt{n-2}}{\sqrt{1-r 2}}
$$

Keterangan :

$\mathrm{t}$ : Nilai uji $\mathrm{t}$

$r$ : Nilai Efisiensi Korelasi

$\mathrm{n}$ : Jumlah Sampel

Kriteria pengujian sebagai berikut :

$\mathrm{H}_{0}$ : bi $=0$, artinya secara persial variabel-variabel bebas (harga, kualitas produk, pelayanan dan psikologis) tidak mempunyai pengaruh yang signifikan terhadap variabel terikat (minat beli konsumen).

$\mathrm{H}_{\mathrm{a}}$ : bi $\neq 0$, artinya secara persial variabel-variabel bebas (harga, kualitas produk, pelayanan dan psikologis) mempunyai pengaruh signifikan terhadap variabel terkait (minat beli konsumen)

Dasar pengambilan keputusan menurut Sanusi (2011) adalah dengan menggunakan angka probabilitas signifikan, yaitu: 
a. Bila $t_{\text {hitung }} \geq t_{\text {tabel }}$ dan $-t_{\text {hitung }} \leq-t_{\text {tabel }}$ dan nilai signifikan $t<$ tingkat signifikan $5 \%$ $(0,05)$, maka $H_{o}$ ditolak dan $H_{a}$ diterima. Hal ini berarti ada pengaruh yang signifikan dari masing-masing variabel bebas terhadap variabel terikat secara parsial.

b. Bila $t$ hitung $<t_{\text {tabel }}$ dan $-t_{\text {hitung }}>-t_{\text {tabel }}$ dan nilai signifikan $t>$ tingkat signifikan $5 \%$ $(0,05)$, maka $\mathrm{H}_{\alpha}$ diterima dan $\mathrm{H}_{\mathrm{a}}$ ditolak. Hal ini berarti tidak ada pengaruh yang signifikan dari masing-masing variabel bebas terhadap variabel terikat secara parsial.

c. Mencari $\mathrm{t}_{\text {tabel }}: d f=\mathrm{n}-\mathrm{k}\left(\frac{\propto}{2}\right)$

Dimana : $d f$ : degree of fredom

$n$ : jumlah sampel

$\mathrm{k}$ : jumlah variabel bebas dan variabel terikat $(\propto$ : $5 \%, 0,005)$

3 Uji Simultan (Uji F)

Uji F dilakukan untuk melihat secara serentak atau bersama-sama bagaimana pengaruh variabel X terhadap Y. Rumus uji F yang dikutip dari Sujerwani (2012) adalah sebagai berikut:

$$
F=\frac{R^{2} / k}{\left(1-R^{2}\right)(N-k-1)}
$$

Keterangan :

F : Nilai F hitung

$\mathrm{R}^{2}$ : Koefisien determinasi

$\mathrm{n}$ : Jumlah sampel

$\mathrm{K}$ : Banyaknya variabel bebas dan variabel terikat.

Kriteria pengujian dengan taraf signifikan $5 \%(0,05)$ adalah sebagai berikut:

Ho : $b_{1}=b_{2}=b_{3}=0$, artinya variabel-variabel bebas (harga, kualitas produk, pelayanan dan psikologis) tidak mempunyai pengaruh yang signifikan secara bersama-sama terhadap variabel terikat (minat beli konsumen).

$\mathrm{H}_{\mathrm{a}}: \mathrm{b}_{1} \neq \mathrm{b}_{2} \neq \mathrm{b}_{3} \neq 0$, variabel-variabel bebas, (harga, kualitas produk, pelayanan dan psikologis) mempunyai pengaruh yang signifikan terhadap variabel terikat (minat beli konsumen).

Dasar pengambilan keputusan (Sanusi, 2011) adalah dengan menggunakan angka probabilitas ialah sebagai berikut :

a. Jika $F_{\text {hitung }} \geq \mathrm{F}_{\text {tabel }}$ dan nilai Sig $<0,005$, maka $\mathrm{H}_{0}$ ditolak dan $\mathrm{H}_{\mathrm{a}}$ diterima, artinya secara simultan variabel independen mempunyai pengaruh yang signifikan terhadap variabel dependen.

b. Jika $\mathrm{F}_{\text {hitung }}<\mathrm{F}_{\text {tabel }}$ dan nilai Sig $>0,005$, maka $\mathrm{H}_{0}$ diterima dan $\mathrm{H}_{\mathrm{a}}$ ditolak, artinya secara simultan variabel independen tidak mempunyai pengaruh yang signifikan terhadap variabel dependen.

c. Mencari $\mathrm{F}_{\text {tabel }}$ : $d f_{1}=\mathrm{K}-1$

$$
d f_{2}=\mathrm{n}-\mathrm{K}
$$

Dimana : $d f$ : degree of freedom 


\section{$\mathrm{n}$ : Jumlah Sampel \\ $\mathrm{K}$ : Jumlah Variabel Bebas dan Variabel Terikat}

4 Koefisien Determinasi (Kd)

Koefisien determinasi $\left(\mathrm{R}^{2}\right)$ bertujuan untuk mengetahui tingkat ketetapan paling baik dalam analisis regresi, dimana hal yang ditunjukkan oleh besarnya koefisiensi determinan $\left(\mathrm{R}^{2}\right)$ antara 0 dan 1 . Koefisiensi determinan $\left(\mathrm{R}^{2}\right)$ nol variabel independen sama sekali tidak berpengaruh terhadap variabel dependen dan sebaliknya (Sanusi, 2011) rumusan koefisien determinan (Kd) yaitu:

$$
\mathrm{R}^{2}=1-\frac{\text { RSS }}{\text { TSS }}
$$

Keterangan:

$$
\begin{array}{ll}
\mathrm{R}^{2} & : \text { Koefisien Determinasi } \\
\mathrm{RSS} & \text { : Residual Sum of squres } \\
\mathrm{TSS} & : \text { Total Sum of squres }
\end{array}
$$

Dimana apabila :

$\mathrm{R}^{2}=0$, artinya pengaruh variabel $\mathrm{X}$ terhadap variabel $\mathrm{Y}$, lemah.

$\mathrm{R}^{2}=1$, artinya pengaruh variabel $\mathrm{X}$ terhadap variabel $\mathrm{Y}$, Kuat.

Pedoman pemberian interpretasi koefisien korelasi sebagai berikut:

Tabel 2. Tinggi Rendahnya Koefisien Determinasi

\begin{tabular}{cc}
\hline Pernyataan & Keterangan \\
\hline $0,80-1,000$ & Sangat Kuat \\
$0,60-0,799$ & Kuat \\
$0,40-0,599$ & Cukup Kuat \\
$0,20-0,399$ & Rendah \\
$0,00-0,199$ & Sangat Rendah \\
\hline
\end{tabular}

Sumber : Riduwan dan Kuncoro (2017)

\section{HASIL DAN PEMBAHASAN}

\section{Minat Beli Konsumen}

Untuk menguji hipotesa yang pertama dalam pembelian tempe pada UD. Yuzak Kecamatan Panji Kabupaten Situbondo dilakukan dengan analisis deskriptif menggunakan index kategori.

Sebelum menentukan index kategori, terlebih dahulu menentukan interval pada setiap kategori dari minat beli konsumen yang akan dijadikan acuan untuk mencari hipotesa.

$$
\begin{aligned}
& \text { Interval Presentase }=\frac{100 \%}{\text { Kelas Interval }} \\
& \text { Interval Presentase }=\frac{100 \%}{5}=20
\end{aligned}
$$

Maka tabel kelas intervalnya adalah sebagai berikut. 
Tabel 3. Kelas Interval Minat Beli Konsumen

\begin{tabular}{llc} 
& \multicolumn{1}{c}{ Kelas } & Keterangan \\
\hline $0 \%$ & $-19,99 \%$ & Sangat Rendah \\
$20 \%$ & $-39,99 \%$ & Rendah \\
$40 \%$ & $-59,99 \%$ & Netral atau Cukup \\
$60 \%$ & $-79,99 \%$ & Tinggi \\
$80 \%$ & $-100 \%$ & Sangat Tinggi \\
\hline
\end{tabular}

Sumber : Sujarweni 2012

Setelah interval kelas ditemukan untuk nantinya menempatkan minat beli terdapat pada kategori sangat tinggi sampai sangat rendah maka kemudian dilanjutkan untuk mengetahui index kategorinya. Index kategori digunakan untuk menentukan variabel minat beli memiliki kategori rendah ataupun tinggi pada suatu penelitian. Rumus index kategori dapat diuraikan sebagai berikut:

$$
\text { Index Kategori \% = Total Skor / (Y.I) x 100\% }
$$

Keterangan:

Total Skor $=$ Jumlah perolehan skor pada setiap indikator

$\mathrm{Y}=$ Jumlah skor tertinggi skala likert $\mathrm{x}$ jumlah responden $(5 \times 97=485)$

I $=$ Jumlah pernyataan dalam setiap indikator

Tabel 4. Penghitungan Minat Beli Konsumen

\begin{tabular}{ccccc}
\hline \multicolumn{5}{c}{ Minat Beli Konsumen } \\
\hline Y1 & Y2 & Y3 & Y4 & Jumlah \\
\hline 435 & 440 & 422 & 410 & 1.707 \\
\hline
\end{tabular}

Sumber: Data penelitian diolah

Index Kategori Minat Beli \%

$$
\begin{aligned}
& =\text { Total Skor } /(\mathrm{YxI}) \times 100 \\
& =1.707 /(485 \times 4) \times 100 \\
& =1.707 / 1.940 \times 100 \\
& =87,99 \%
\end{aligned}
$$

Berdasarkan tabel di atas maka perolehan index kategori yang diperoleh dari keempat variabel tersebut adalah $87,99 \%$ sehingga berada pada ketegori sangat tinggi. Hal ini dapat dibuktikan dengan adanya perasaan senang, mengatakan hal baik setelah membeli, merekomendasikan kepada konsumen lain dan niat untuk membeli ulang produk tempe dari konsumen yang sudah baik. Tanggapan responden pada pernyataan minat beli konsumen menunjukkan bahwa sebagian besar responden memberikan jawaban sangat setuju, sehingga hal ini menunjukkan bahwa minat beli konsumen akan produk tempe pada UD. Yuzak sudah bisa dikatakan berjalan dengan baik, sebab konsumen sudah banyak yang senang membeli produk tempe pada UD. Yuzak dikarenakan konsumen banyak yang meyakini dan merasakan sendiri bahwa produk tempe tersebut memiliki kualitas yang bagus dan enak sehingga konsumen akan datang lagi untuk membeli tempe tersebut serta akan merekomendasikan pembelian tempe dari UD. Yuzak kepada tetangga, saudara dan orang lainnya.

Minat beli konsumen dalam membeli tempe pada UD. Yuzak juga tidak terlepas dari adanya kualitas pelayanan yang baik dan adanya psikologis konsumen untuk membeli 
tempe UD. Yuzak. Pelayanan yang diterima konsumen berupa tempat penjualan tempe pada UD. Yuzak sangat nyaman buat konsumen dari segi tempat dan suasana sehingga konsumen merasa enak bila membelinya, fasilitas yang diberikan cukup memadai seperti tempat duduk, tempat berteduh bahkan toilet sehingga konsumen merasa dimanjakan dan UD. Yuzak sangat ramah dan selalu tersenyum dalam melayani konsumen dalam membeli tempe. Psikologis yang dirasakan konsumen karena UD. Yuzak sudah banyak dikenal masyarakat dalam produksi tempe sehingga konsumen merasa sudah percaya akan kualitas tempenya, terpenuhinya permintaan konsumen akan pelayanan yang baik dalam membeli tempe dan konsumen merasa sudah berlangganan cukup lama sehingga minat belinya tidak pernah berubah dalam hal pembelian tempe.

\section{Faktor yang Mempengaruhi Minat Beli Konsumen}

Untuk menguji hipotesa yang kedua yaitu mengetahui faktor yang mempengaruhi minat beli konsumen pada UD. Yuzak Kecamatan Panji Kabupaten Situbondo dilakukan dengan analisis regresi linier berganda dan nantinya dari analisis regresi linier berganda juga dilakukan dengan uji F, uji t dan koefisien determinansi

\section{Persamaan Regresi}

Untuk menguji hipotesis, teknik analisis yang digunakan adalah teknik analisis regresi linier berganda yang dihitung dengan menggunakan penghitungan SPSS versi 22 For Windows, yaitu untuk menguji hipotesis yang diajukan. Adapun hasil perhitungan analisis regresi linier melalui SPSS versi 22 For Windows, untuk menguji hipotesis dapat dilihat pada tabel berikut:

Tabel 5. Ringkasan Hasil Analisis Regresi Linier Berganda

\begin{tabular}{lrc}
\hline \multicolumn{1}{c}{ Variabel Independen } & Koefisien Regresi & Galat \\
\hline (Konstanta) & 6,677 & 3,210 \\
Harga & 0,158 & 0,153 \\
Kualitas & 0,093 & 0,131 \\
Pelayanan & 0,315 & 0,140 \\
Psikologis & 0,245 & 0,120 \\
\hline
\end{tabular}

Variabel Dependen : Minat Beli Konsumen

Sumber: Data penelitian diolah

Analisis regresi berganda:

$$
\begin{aligned}
Y & =a+b_{1} X_{1}+b_{2} X_{2}+b_{3} X_{3}+b_{4} X_{4} \\
& =6,877+0,158 X_{1}+0,093 X_{2}+0,315 X_{3}+0,245 X_{4}
\end{aligned}
$$

Arti persamaan regresi diatas adalah sebagai berikut:

a. Konstanta sebesar 6,877 menyatakan bahwa jika variabel independen (harga, kualitas, pelayanan dan psikologis) dianggap konstan, maka rata-rata minat beli konsumen memilih produk tempe pada UD. Yuzak sebesar 6,877.

b. Koefisien regresi harga sebesar 0,158 menyatakan bahwa setiap peningkatan variabel harga sebesar 1\%, maka minat beli konsumen meningkat 0,158\% dengan asumsi variabel lain (kualitas, pelayanan dan psikologis) konstan.

c. Koefisien regresi kualitas sebesar 0,093 menyatakan bahwa setiap peningkatan variabel kualitas sebesar 1\%, maka minat beli konsumen meningkat 0,093\% dengan asumsi variabel lain (harga, pelayanan dan psikologis) konstan. 
d. Koefisien regresi pelayanan sebesar 0,315 menyatakan bahwa setiap peningkatan variabel pelayanan sebesar 1\%, maka minat beli konsumen meningkat 0,315\% dengan asumsi variabel lain (harga, kualitas dan psikologis) konstan.

e. Koefisien regresi psikologis sebesar 0,245 menyatakan bahwa setiap peningkatan variabel psikologis sebesar 1\%, maka minat beli konsumen meningkat 0,245\% dengan asumsi variabel lain (harga, kualitas dan pelayanan) konstan.

\section{Uji Simultan ( Uji F )}

Uji simultan atau uji F merupakan uji secara bersama-sama untuk menguji pengaruh signifikan variabel harga, kualitas, pelayanan dan psikologis terhadap minat beli konsumen. Rumus $\mathrm{F}_{\text {tabel }} \quad \mathrm{d} f \mathrm{NI}=\mathrm{n}-\mathrm{k}$ dan $\mathrm{d} f \mathrm{~N} 2=\mathrm{k}-1$, maka hasilnya sebagai berikut: $\mathrm{d} f \mathrm{NI}=\mathrm{n}-\mathrm{k}=97-5=92, \mathrm{~d} f \mathrm{~N} 2=\mathrm{k}-1=5-1=4$, jadi untuk $\mathrm{F}_{\text {tabel }}$ pada kolom ke 4 baris 92 yaitu $=2,471$ ( nilai $F_{\text {tabel}}$ ). Berdasarkan pengujian hipotesis dengan perhitungan analisis regresi linier berganda menggunakan komputerisasi program SPSS for Wimdows release 22,00, hasil uji F dapat dilihat pada tabel berikut:

Tabel 6. Hasil Penghitungan Uji F

\begin{tabular}{|c|c|c|c|c|c|}
\hline $\begin{array}{c}\text { Sumber } \\
\text { Keterangan }\end{array}$ & $\begin{array}{l}\text { Jumlah } \\
\text { Kuadrat }\end{array}$ & Derajat Bebas & $F_{\text {hitung }}$ & $F_{\text {tabel }}$ & Sig \\
\hline Regresi & 24,241 & 4 & & & \\
\hline Galat & 153,079 & 92 & 3,642 & 2,471 & 0,008 \\
\hline Total & 177,320 & 94 & & & \\
\hline
\end{tabular}

Sumber: Data penelitian diolah

Dari uji ANOVA atau $F$ test diatas, didapat nilai $F$ hitung sebesar 3,642. Nilai $F$ hitung lebih besar $\mathrm{F}$ tabel $(3,642$ lebih besar 2,471) dengan tingkat signifikansi 0,008. Karena nilai signifikan yang diperoleh kurang dari 0,05 , menunjukan bahwa nilai $\mathrm{F}$ yang diperoleh tersebut signifikan, maka dapat dikatakan bahwa variabel independen yang terdiri atas harga, kualitas, pelayanan dan psikologis secara bersama-sama berpengaruh terhadap minat beli konsumen memilih produk tempe pada UD. Yuzak.

\section{Uji Parsial ( Uji t )}

Pengujian hipotesis secara parsial ini dimaksudkan untuk menguji seberapa besar pegaruh dari masing-masing variabel bebas yaitu terdiri atas harga $\left(\mathrm{X}_{1}\right)$, kualitas $\left(\mathrm{X}_{2}\right)$, pelayanan $\left(\mathrm{X}_{3}\right)$, psikologis $\left(\mathrm{X}_{4}\right)$ terhadap minat beli konsumen $(\mathrm{Y}) \cdot d f=\mathrm{n}-\mathrm{k}=97-5=92$ $=1,986$ (nilai tabel)

Tabel 7. Ringkasan Hasil Uji t

\begin{tabular}{lccc}
\hline \multicolumn{1}{c}{ Variabel } & $\mathrm{t}_{\text {hitung }}$ & $\mathrm{t}_{\text {tabel }}$ & Sig \\
\hline Harga & 1,033 & & 0,304 \\
Kualitas & 0,710 & \multirow{2}{*}{1,986} & 0,480 \\
Pelayanan & 2,248 & & 0,027 \\
Psikologis & 2,039 & & 0,044 \\
\hline
\end{tabular}

Sumber: Data penelitian diolah

Berdasarkan tabel diatas, dapat diuraikan bahwa nilai thitung untuk variabel harga sebesar 1,033 . Sementara itu nilai pada $t_{\text {tabel }}$ distribusi $5 \%$ sebesar 1.986 , maka $t_{\text {hitung }} 1,033$ lebih kecil dari tabel 1,986 , hal ini berarti variabel harga tidak mempunyai pengaruh positif 
dan signifikan. Hal ini juga diperkuat dengan nilai signifikan 0,304 lebih besar dari 0,05 artinya variabel harga $\left(\mathrm{X}_{1}\right)$ tidak berpengaruh secara parsial terhadap minat beli konsumen dalam pembelian produk tempe pada UD. Yuzak. Harga tidak berpengaruh terhadap minat beli konsumen tempe pada UD. Yuzak karena mayoritas harga tempe yang ditawarkan oleh setiap tempat pembuatan tempe terbilang sama sehingga konsumen merasa harga tempe tidak terlalu murah dan mahal bila dibandingkan tempe tempat lain.

Nilai $t_{\text {hitung }}$ untuk variabel kualitas sebesar 0,710 . Sementara itu nilai pada tabel distribusi $5 \%$ sebesar 1.986, maka thitung 0,710 lebih kecil dari $t_{\text {tabel }} 1,986$, hal ini berarti variabel kualitas tidak mempunyai pengaruh positif dan signifikan. Hal ini juga diperkuat dengan nilai signifikan 0,480 lebih besar dari 0,05 artinya variabel kualitas $\left(\mathrm{X}_{2}\right)$ tidak berpengaruh secara parsial terhadap minat beli konsumen dalam pembelian produk tempe pada UD. Yuzak Kualitas tidak berpengaruh terhadap minat beli konsumen tempe pada UD. Yuzak karena konsumen UD. Yuzak merupakan pelanggan tetap sehingga konsumen sudah yakin bahwa kualitas tempe yang dihasilkan UD. Yuzak hampir sama dengan kualitas tempe lainnya.

Nilai $t_{\text {hitung }}$ untuk variabel pelayanan sebesar 2,248. Sementara itu nilai pada $t_{\text {tabel }}$ distribusi $5 \%$ sebesar 1.986, maka $t_{\text {hitung }} 2,248$ lebih besar dari $t_{\text {tabel }} 1,986$, hal ini berarti variabel pelayanan mempunyai pengaruh positif dan signifikan. Hal ini juga diperkuat dengan nilai signifikan 0,027 lebih kecil dari 0,05 artinya variabel pelayanan $\left(\mathrm{X}_{3}\right)$ berpengaruh secara parsial terhadap minat beli konsumen dalam pembelian produk tempe pada UD. Yuzak. Pelayanan berpengaruh terhadap minat beli konsumen tempe pada UD. Yuzak karena meskipun harga dan kualitas tempe hampir sama dengan tempat lainnya, akan tetapi pelayanan yang diberikan pengusaha UD. Yuzak terhadap konsumen sangat baik, pengusaha ramah dan selalu tersenyum melayani konsumen sehingga konsumen merasa senang membeli tempe pada UD. Yuzak dan minat belinya tinggi.

Nilai $t_{\text {hitung }}$ untuk variabel psikologis sebesar 2,039. Sementara itu nilai pada $t_{\text {tabel }}$ distribusi $5 \%$ sebesar 1.986, maka $t_{\text {hitung }} 2,039$ lebih besar dari $t_{\text {tabel }} 1,986$, hal ini berarti variabel psikologis mempunyai pengaruh positif dan signifikan. Hal ini juga diperkuat dengan nilai signifikan 0,044 lebih kecil dari 0,05 artinya variabel psikologis $\left(\mathrm{X}_{4}\right)$ berpengaruh secara parsial terhadap minat beli konsumen dalam pembelian produk tempe pada UD. Yuzak. Psikologis berpengaruh terhadap minat beli konsumen tempe pada UD. Yuzak karena konsumen merasa UD. Yuzak sudah banyak dikenal masyarakat dalam produksi tempe sehingga konsumen merasa sudah percaya akan kualitas tempenya, terpenuhinya permintaan konsumen akan pelayanan yang baik dalam membeli tempe dan konsumen merasa sudah berlangganan cukup lama sehingga minat belinya tidak pernah berubah.

\section{Koefisien Determinasi ( $\left.\mathbf{R}^{2}\right)$}

Hasil pengujian koefisian determinasi $\left(\mathrm{R}^{2}\right)$ dengan perhitungan analisis regresi linier berganda menggunakan komputerisasi program SPSS for Wimdows release 22,00, yaitu menghasilkan nilai $\mathrm{R}^{2}$ sebesar 0,137 dan bila dipersenkan menjadi 13,7\% (Lampiran 6). Nilai koefisien determinasi atau $\mathrm{R}$ square sebesar 0,137 menunjukkan bahwa seluruh variabel bebas harga, kualitas, pelayanan dan psikologis mempunyai kontribusi sebesar $13,7 \%$ terhadap variabel terikat minat beli konsumen dengan tingkat ketetapannya sangat rendah, dan sisanya sebesar $86,3 \%$ dipengaruhi oleh faktor-faktor lain yang tidak masuk 
dalam penelitian.

Berdasarkan pendapat dari peneliti, 86,3\% faktor-faktor lain yang mempengaruhi minat beli konsumen adalah lokasi, promosi, merek dan proses. Dengan adanya lokasi yang strategis maka konsumen dengan mudah tahu produk yang ditawarkan, promosi yang luas akan mempercepat proses pengetahuan konsumen akan produk tempe, merek dan proses pembuatan tempe juga meningkatkan daya beli masyarakat karena sudah dapat dipercaya. Namun keempat faktor lain tersebut masih belum tentu juga berpengaruh terhadap minat beli konsumen tempe karena belum adanya penelitian dan uji regresi akan variabel tersebut sehingga pendapat yang disampaikan peneliti merupakan hipotesis semata.

Minat beli konsumen akan produk tempe UD. Yuzak berada pada kategori sangat tinggi, hal ini berarti permintaan akan tempe yang diproduksi oleh UD. Yuzaktinggi sehingga banyak yang minat terhadap produk tempenya. Tingginya minat beli tempe masyarakat tidak terlepas dari adanya kebutuhan yang sudah memang dimiliki oleh konsumen akan tempe, sebab tempe merupakan makanan wajib sebagai lauk maupun olahan produk lainnya yang tidak bisa lepas dari makanan sehari-hari masyarakat. Tempe merupakan makanan yang banyak mengandung gizi dan protein nabati dengan harga yang murah sehingga banyak kalangan masyarakat menengah kebawah menyukai produk tersebut sebab masyarakat dulu tidak mampu membeli sumber protein lainnya seperti daging karena harganya yang mahal, padahal masyarakat juga menginginkan peningkatan gizi dan protein yang sama dengan masyarakat kalangan menengah ke atas sehingga dengan adanya tempe sebagai alternatif sumber protein yang murah menjadikan produk tersebut primadono bagi masyarakat terutama masyarakat pedesaan. Lambat laun dengan adanya kemajuan jaman, pasar tempe sudah masuk ke segala jenis kalangan masyarakat dan banyak yang menyukai dan membutuhkannya sehingga minat beli akan tempe semakin tinggi.

\section{Kesimpulan}

Berdasarkan data yang diperoleh dari hasil analisis yang dilakukan maka dapat ditarik kesimpulan sebagai barikut:

1. Minat beli konsumen akan produk tempe yang dijual oleh UD. Yuzak berada pada ketegori sangat tinggi.

2. Faktor-faktor yang mempengaruhi minat beli konsumen tempe pada UD. Yuzak adalah pelayanan dan psikologis, sedangkan harga dan kualitas tidak berpengaruh terhadap minat beli konsumen, hal ini dapat dijabarkan sebagai berikut.

a. Tidak terdapat pengaruh harga terhadap minat beli konsumen produk tempe dengan $t_{\text {hitung }}$ sebesar 1,033 dan $t_{\text {tabel }}$ sebesar 1,986 ( $\left.t_{\text {hitung }}<t_{\text {tabel }}\right)$.

b. Tidak terdapat pengaruh kualitas terhadap minat beli konsumen produk tempe dengan $t$ hitung sebesar 0,710 dan $t_{\text {tabel }}$ sebesar 1,986 ( $\left.t_{\text {hitung }}<t_{\text {tabel }}\right)$.

c. Terdapat pengaruh pelayanan terhadap minat beli konsumen produk tempe dengan $t$ hitung sebesar 2,248 dan $t_{\text {tabel }}$ sebesar 1,986 ( $\left.t_{\text {hitung }}>t_{\text {tabel }}\right)$.

d. Terdapat pengaruh psikologis terhadap minat beli konsumen produk tempe dengan $t$ hitung sebesar 2,039 dan $t_{\text {tabel }}$ sebesar 1,986 ( $\left.t_{\text {hitung }}>t_{\text {tabel }}\right)$. 


\section{REFERENSI}

Anoraga, P. \& J. Sudantoko. 2002. Koperasi, Kewirausahaan dan Usaha Kecil. Rineka Cipta. Jakarta

Riduwan dan Kuncoro, A. E. 2017. Cara Menggunakan dan Memakai Path Analysis. Alfabeta. Bandung

Rosnani. 2010. Riset Pemasaran dan Perilaku Konsumen. Penerbit PT. Gramedia Pustaka Utama. Jakarta

Sanusi, A. 2011. Metode Penelitian Bisnis. Jakarta: Salemba Empat

Sarwono, B. 2004. Membuat Aneka Tahu. Penebar Swadaya. Jakarta

Sugiyono. 2017. Metode Penelitian Kuantitatif, Kualitatif dan $R \& D$. Alfabeta. Bandung

Sujarweni, V.W. 2012. Statistik Untuk Penelitian. Graha Ilmu. Yogyakarta 